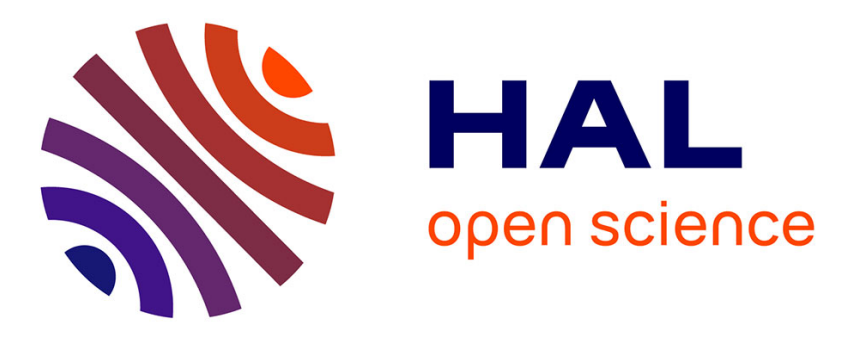

\title{
Towards miniaturization of concentrated photovoltaics (CPV): impact on fabrication, performance and robustness of solar cells
}

Pierre Albert, Gwenaelle Hamon, Maite Volatier, Yannick Deshayes, Abdelatif Jaouad, Vincent Aimez, Laurent Bechou, Maxime Darnon

\section{To cite this version:}

Pierre Albert, Gwenaelle Hamon, Maite Volatier, Yannick Deshayes, Abdelatif Jaouad, et al.. Towards miniaturization of concentrated photovoltaics (CPV): impact on fabrication, performance and robustness of solar cells. 2020 IEEE 47th Photovoltaic Specialists Conference (PVSC), IEEE, Jun 2020, Calgary (virtual), Canada. pp.1268-1273, 10.1109/PVSC45281.2020.9300898 . hal-03109711

\section{HAL Id: hal-03109711 \\ https://hal.science/hal-03109711}

Submitted on 13 Jan 2021

HAL is a multi-disciplinary open access archive for the deposit and dissemination of scientific research documents, whether they are published or not. The documents may come from teaching and research institutions in France or abroad, or from public or private research centers.
L'archive ouverte pluridisciplinaire HAL, est destinée au dépôt et à la diffusion de documents scientifiques de niveau recherche, publiés ou non, émanant des établissements d'enseignement et de recherche français ou étrangers, des laboratoires publics ou privés. 


\section{Towards miniaturization of concentrated photovoltaics (CPV): impact on fabrication, performance and robustness of solar cells}

\author{
Pierre Albert \\ LN2, 3IT \\ CNRS Université de Sherbrooke, \\ Sherbrooke, Qc, Canada \\ IMS, CNRS U. de Bordeaux, \\ Talence, France \\ pierre.albert@usherbrooke.ca \\ Abdelatif Jaouad \\ LN2, 3IT \\ CNRS Université de Sherbrooke, \\ Sherbrooke, Qc, Canada
}

\author{
Gwenaëlle Hamon \\ LN2, 3IT \\ CNRS Université de Sherbrooke, \\ Sherbrooke, Qc, Canada
}

Vincent Aimez LN2, 3IT

CNRS Université de Sherbrooke, Sherbrooke, Qc, Canada

\author{
Maïté Volatier \\ LN2, 3IT \\ CNRS Université de Sherbrooke, \\ Sherbrooke, Qc, Canada
}

Laurent Béchou IMS

CNRS Université de Bordeaux, Talence, France LN2, $3 I T$

CNRS Université de Sherbrooke, Sherbrooke, Qc, Canada
Yannick Deshayes

IMS

CNRS Université de Bordeaux, Talence, France

Maxime Darnon LN2, 3IT

CNRS Université de Sherbrooke, Sherbrooke, Qc, Canada

\begin{abstract}
Micro-CPV is emerging with the potential to overcome conventional CPV weaknesses. With cells miniaturization, fabrication processes, electrical performance and potentially reliability are impacted. We present here improved fabrication techniques to provide high performance microcells and high wafer throughput. We demonstrate cells fabrication with active area ranging from $1 \mathrm{~mm}^{2}$ to $0.076 \mathrm{~mm}^{2}$ with $8.1 \%$ reduced VoC for smallest cells, attributed to perimeter surface recombination. All cells present no dramatic failure during passive or active ageing tests, which is promising for the future development of micro-CPV technologies.
\end{abstract}

Keywords-multijunction solar cells, micro-CPV, microfabrication, perimeter recombination, reliability

\section{INTRODUCTION}

Concentrated Photovoltaics (CPV) technology relies on the concentration of the sunlight onto small (typically $\mathrm{mm}^{2}$ to $\mathrm{cm}^{2}$ ) and highly efficient (III-V-based, typically triple junctions) cells. However, this-technology cost is still too high to be widely adopted. An emerging approach consists in miniaturizing modules dimensions (micro-CPV). Submillimeter multijunction cells are the cores of this innovative technology as they can overcome some of the limitations that make the standard CPV unwelcome. Low-temperature operation is the key for high electrical performance and for an improved reliability. Due to their small dimensions, easier strategies for thermal management can be offered with micro-cells [1]. In addition, smaller cells show less resistive losses thus higher efficiency is theoretically achievable under very high concentration.

Whereas micro-CPV and microcells seem of great interest, some challenges exist. First, fabrication processes must be adapted to provide good performance and high wafer throughput, for which the conventional saw dicing is limiting. Second, perimeter recombination is known to affect electrical characteristics, and an efficient passivation appears to be necessary in order to lower performance losses. This is mitigated by saturation of traps under high-intensity illumination making microcells assuredly good candidates for high-concentration photovoltaics [2]. Perimeter effect was also shown to influence the reliability of GaAs 1- $\mathrm{mm}^{2}$ solar cells, but no investigation focused on impact of size on multijunction solar cells reliability to our knowledge was reported [3]. CPV-cells operating conditions are complex (high-intensity light, heat, temperature variations, humidity, etc.) and thus, accelerated ageing tests design is not straightforward. A conventional technique used by the CPV community for simulating cell photogeneration ageing deals with active storage, in which cells are current-biased during the accelerated tests [3]-[7]. However, such a bias is quite different from operating conditions [6]. Passive thermal storage has also been considered but was demonstrated to be more aggressive to CPV cells compared to active storage [7]. Therefore, no perfect solution exists and ageing tests need to be considered with hindsight.

In this paper, we propose processes based on microfabrication techniques to fabricate $\mathrm{InGaP} /(\mathrm{In}) \mathrm{GaAs} / \mathrm{Ge}$ CPV cells with submillimeter dimensions (down to $0.068 \mathrm{~mm}^{2}$ ). One-sun characterization of cells from $1 \mathrm{~mm}^{2}$ to $0.076 \mathrm{~mm}^{2}$ shows the dependency between electrical performance and cell size, which highlights perimeter recombination. The effect of reducing cell dimensions on long-term performance is also investigated. Two strategies of accelerated ageing tests, based on thermal step stress, are developed: a passive (thermal stress only) and an active (thermal + current stress) test. Whereas the type of test shows different behaviors of performance changes, 
the $0.076-\mathrm{mm}^{2}$ cells have demonstrated a good robustness, higher than the one of $1-\mathrm{mm}^{2}$ cells. Finally, the impact of perimeter recombination effect on cells degradation is discussed, as well as the impact of test type on performance.

\section{DEVICES FABRICATION}

A commercial structure of $\mathrm{InGaP} /(\mathrm{In}) \mathrm{GaAs} / \mathrm{Ge}$ was chosen as the building block to develop the fabrication processes. The first step consists in depositing Al-based or Au-based contacts as emitter electrodes to define the front contact grid. Cells are then electrically isolated in individual devices, using inductively coupled plasma etching (ICP) with a combination of $\mathrm{SiCl}_{4}, \mathrm{Cl}_{2}$ and $\mathrm{H}_{2}$ [8]. Then, the Al-based or Au-based base contact is deposited by evaporation either on the backside of the wafer or on the front side close to the mesa. Both contact methods lead to the same electrical results [2]. Then, an antireflective coating (ARC) made of $\mathrm{SiN}_{\mathrm{X}} \mathrm{H}_{Y} / \mathrm{SiO}_{\mathrm{X}} \mathrm{H}_{Y}$ is deposited by plasmaenhanced chemical vapor deposition (PECVD). Besides increasing optical absorption of the cell, such ARC permits a passivation effect, which can limit perimeter recombination rate [9]. The ARC is then opened on metallization to access the electrical contacts. The fabrication processes ends by singulating cells from the wafer. This step is performed by plasma dicing [10]. Indeed, compared to the conventional saw dicing, plasma dicing offers a stress-and-damages-free singulation with flexibility in the desired cell shapes. Moreover, narrow dicing lines offered by such technique $(10-\mu \mathrm{m})$ allow the wafer yield to be more than doubled with microcells, compared to saw dicing. After this step, devices fabrication is complete and Fig. 2 shows some examples of fabricated front-contacted cells, with various shapes (rectangular, hexagonal or circular active area), dimensions (from $12.25 \mathrm{~mm}^{2}$ to $0.068 \mathrm{~mm}^{2}$ ) and contact methods (front or standard contacts).

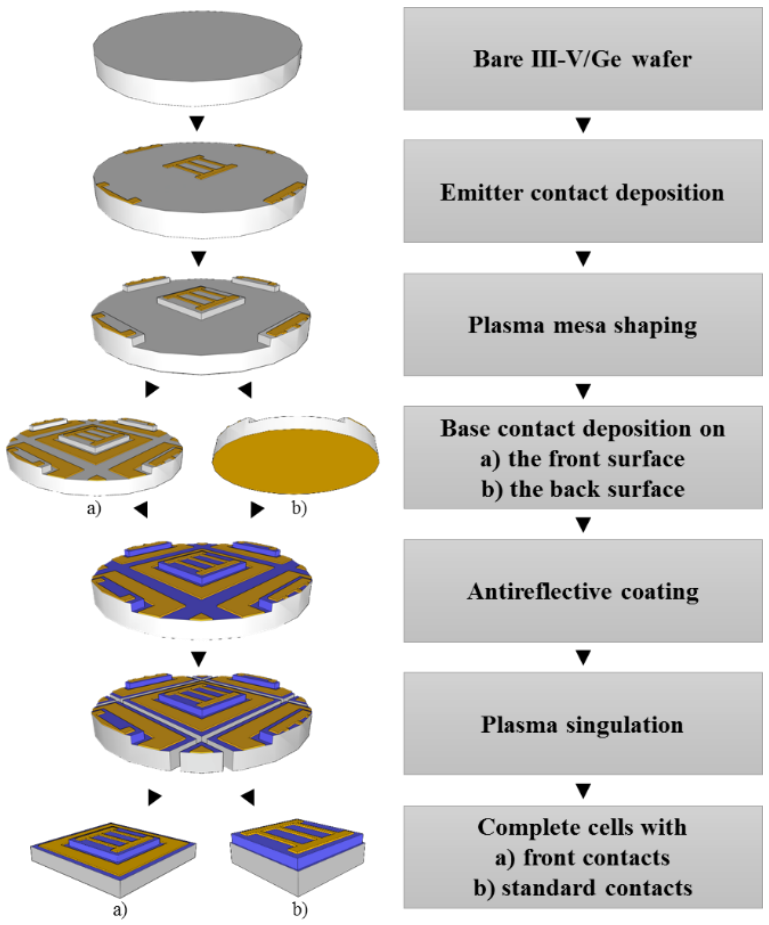

Fig. 1. Major steps for fabrication of solar cells with a) front contacts and b) standard contacts.

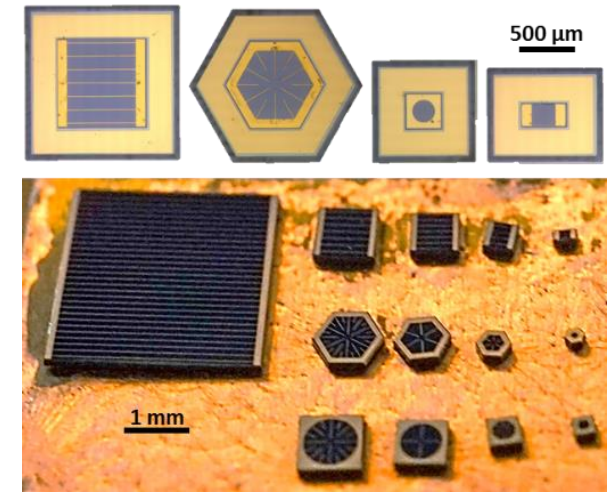

Fig. 2. Images of fabricated solar cells with front contacts (top) and standard contacts (bottom). Cell area ranges from $12.25 \mathrm{~mm}^{2}$ to $0.068 \mathrm{~mm}^{2}$

\section{Electrical Performance}

Fabricated cells were characterized under one-sun illumination $\left(1000 \mathrm{~W} / \mathrm{m}^{2}\right.$, AM1.5g, $\left.25{ }^{\circ} \mathrm{C}\right)$ with an Oriel $1 \mathrm{~A}$ solar simulator. In Fig. 3, current densities $(J)$ of rectangular cells with mesa surface of $1 \mathrm{~mm}^{2}, 0.25 \mathrm{~mm}^{2}$ and $0.076 \mathrm{~mm}^{2}$ are plotted along voltage $(V)$. All cells show good characteristics with open-circuit voltage $\left(V_{O C}\right)>2.12 \mathrm{~V}$ and fill factor $(F F)>$ $82 \%$. The changes in cell size do not affect the $J_{S C}$. Extracted $F F$ are between $82.3 \%\left(0.076-\mathrm{mm}^{2}\right.$ cell $)$ and $85.4 \%\left(1-\mathrm{mm}^{2}\right.$ cell). The slight decrease of $F F$ as the cell size decreases is related to the $V_{O C}$ drop [12]. Indeed, a $V_{O C}$ decrease of $4.4 \%$ can be seen from the plot when cell area is reduced from $1 \mathrm{~mm}^{2}$ to $0.25 \mathrm{~mm}^{2}$. This $V_{O C}$ decline reaches $8.1 \%$ when cell area is reduced from $1 \mathrm{~mm}^{2}$ to $0.076 \mathrm{~mm}^{2}$. All cells were fabricated with the same processes and with the same epitaxial structures, which implies bulk recombination rates are assumed to be the same for all cells. Therefore, the reduction in $V_{O C}$ can be attributed to perimeter recombination effect.

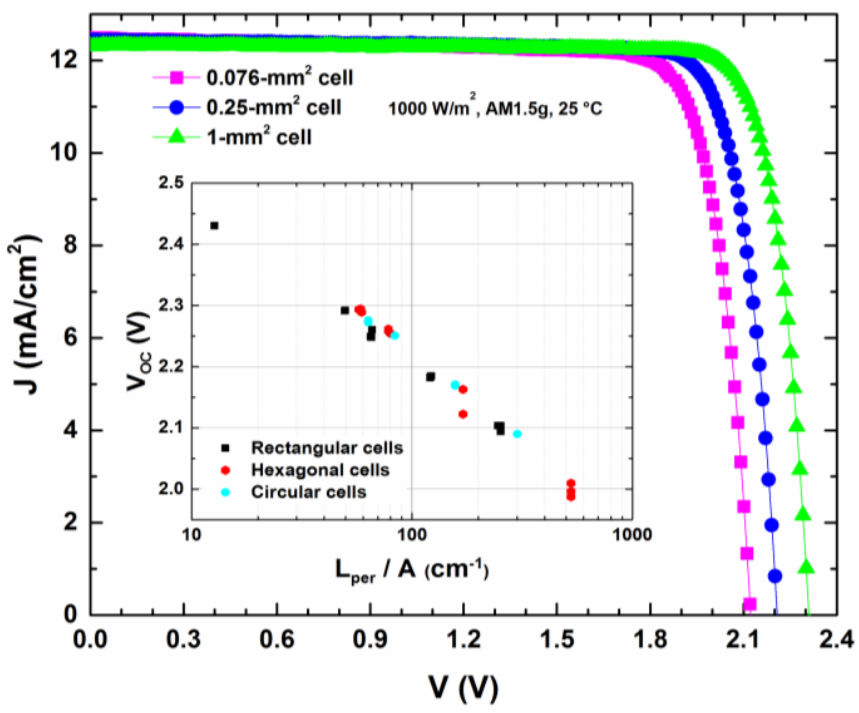

Fig. 3. Current density vs voltage characteristics of $0.076-\mathrm{mm}^{2}, 0.25-\mathrm{mm}^{2}$ and $1-\mathrm{mm}^{2}$ cells. The inset figure shows the open-circuit voltage of cells with various dimensions and geometries along perimeter-to-area ratio. 
Based on a simple one-diode model, one can express $V_{O C}$ of a 3-junction cell as:

$$
V_{O C} \approx \sum_{i=1}^{3} n_{i} \frac{k T}{q} \ln \left[\frac{J_{L, i}}{J_{0, i}}\right]
$$

where $n_{i}$ is the diode ideality factor of subcell $i$, which depends on the recombination processes that occur in the subcell, $k$ is the Boltzmann constant, $T$ is the temperature, $q$ is the electron charge, $J_{L, i}$ is the photogenerated current density of subcell $i$ and $J_{0, i}$ is the reverse saturation dark current density of subcell $i$. $J_{0, i}$ can be expressed as:

$$
J_{0, i}=J_{01, i}+J_{02, s c r, i}+J_{02, p e r, i}
$$

where $J_{01, i}$ is the saturation current density associated with diffusion process in subcell $i, J_{02, s c r, i}$ is the saturation current density associated with the effects in space charge region in subcell $i$ and $J_{02, p e r, i}$ is the saturation current density resulting from recombination at the perimeter of subcell $i$. The latter parameter can be written as:

$$
J_{02, p e r, i}=q n_{i} S_{0, i} L_{S, i} \frac{L_{p e r}}{A}
$$

where $S_{0, i}$ is the surface recombination velocity in subcell $i$, $L_{S, i}$ is the diffusion length of subcell $i, L_{p e r}$ is the cell perimeter and $A$ is the cell area.

Therefore, the quasi-linear relation between $V_{O C}$ and perimeter-to-area ratio $\frac{L_{p e r}}{A}$ observed on the inset of Fig. 3 indicates that $J_{0}$ of at least one subcell varies linearly with $\frac{L_{p e r}}{A}$ and perimeter recombination is more significative than other contributions to the dark current. This proves the high influence of perimeter recombination on small-dimensions cells performance. Dedicated surface passivation could further limit perimeter recombination rate by efficiently passivating recombination centers. Moreover, perimeter recombination centers become saturated under high-intensity light. In a previous study, we demonstrated that the drop in $V_{O C}$ due to small dimensions turns to be insignificant under high concentration $(<2.0 \%$ under $\sim 1300 \mathrm{X}$, even in the absence of a passivating ARC) [2]. Therefore, microcells are particularly of interest for highly concentrated photovoltaics not only thanks to their reduced resistive losses but also to their better efficiency under higher concentration.

\section{ROBUSTNESS ASSESSMENT}

\section{A. Accelerated Test Overview}

Accelerated life tests can be divided in two categories: quantitative and qualitative tests. On the one hand, quantitative accelerated life tests aim at extracting a device lifetime, with the mean time to failure $(M T T F)$ for example. This last can be predicted by observing the cumulated failure distribution during accelerated life test and by extrapolating it to the operation conditions, using an adequate model depending on accelerated parameters $(\mathrm{I}, \mathrm{V}, \mathrm{T}, \ldots)$. It is generally performed on a large number of mature devices from a technological point of view. On the other hand, qualitative tests, that are typically highly accelerated life tests (HALT), aim at highlighting failure modes. It is often coupled with failure analysis to determine the physical mechanisms responsible for the failure. Qualitative ageing tests are typically preliminary tests performed with low-maturity technology to give a feedback particularly on the variability of fabrication processes. Step stress ageing tests (SSAT) are HALT that gradually increase a given stress or a combination of stress parameters on the devices. Multiple parameters can be stressing, but the most relevant parameter is temperature, as most degradation mechanisms are affected by thermal effects.

CPV cells, due to the high-intensity light they convert, are often considered to operate at up to $80{ }^{\circ} \mathrm{C}$, with an nominal operating temperature of $65^{\circ} \mathrm{C}$ for $1-\mathrm{mm}^{2}$ cells operating under $1000 \mathrm{X}$ [4], [5]. Besides high temperature, CPV cells are submitted to large photocurrent densities resulting from the high light intensity they convert into electricity under concentration. Therefore, the most common method for simulating photogeneration during accelerated life tests consists in injecting in the cell a current similar to the one generated in operating conditions.

\section{B. Experimental Procedure}

In our study, SSAT were designed with a gradual temperature storage (passive stress, PSSAT) in a first case and with a gradual temperature storage together with a constant current injection equivalent to $1000 \times I_{S C}$ (active stress, ASSAT) in a second case. Storage temperature was increased by $20{ }^{\circ} \mathrm{C}$ after each week $(168 \mathrm{~h})$, from $85{ }^{\circ} \mathrm{C}$ to $185^{\circ} \mathrm{C}$ (PSSAT) and from $65^{\circ} \mathrm{C}$ to $185{ }^{\circ} \mathrm{C}$ (ASSAT). Step stress temperature storage profiles are shown in Fig. 4 and parameters are summarized in Table 1. Electrical characterization was performed after each ageing step (see Fig 4) with a Keithley 2420 by removing the cells from the thermal chamber and characterizing them under a one-sun illumination

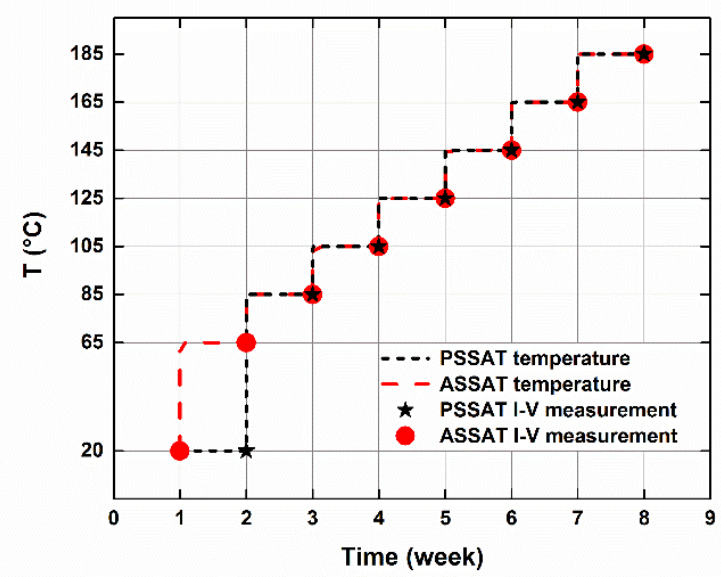

Fig. 4. Stress profiles and $I-V$ measurement occurencies in PSSAT and ASSAT 
TABLE I. STEP STRESS ACCELERATED TEST CONDITIONS AND DEVICES UNDER TEST

\begin{tabular}{|c|c|c|c|c|}
\hline \multirow{2}{*}{$\begin{array}{c}\text { Step stress } \\
\text { accelerated } \\
\text { test }\end{array}$} & \multicolumn{2}{|c|}{ Test conditions } & \multicolumn{2}{|c|}{ Devices under test } \\
\hline & $\begin{array}{c}\text { Thermal } \\
\text { stress }\end{array}$ & $\begin{array}{c}\text { Current } \\
\text { injection }\end{array}$ & Type & Number \\
\hline \multirow{2}{*}{$\begin{array}{c}\text { Passive } \\
\text { (PSSAT) }\end{array}$} & $\begin{array}{c}\text { From } 85{ }^{\circ} \mathrm{C} \\
\text { to } 185^{\circ} \mathrm{C}\end{array}$ & \multirow{2}{*}{ none } & \multirow{2}{*}{ Bare cells } & \multirow{2}{*}{$\begin{array}{l}6 \text { cells, } \\
3 \text { sizes }\end{array}$} \\
\hline & \multirow{2}{*}{$\begin{array}{c}168 \mathrm{~h} \text { steps } \\
20^{\circ} \mathrm{C} \\
\text { increase } \\
\text { between } \\
\text { each step }\end{array}$} & & & \\
\hline \multirow{2}{*}{$\begin{array}{c}\text { Active } \\
\text { (ASSAT) }\end{array}$} & & \multirow{2}{*}{$\begin{array}{l}\text { Equivalent } \\
\text { to } 1000 \times \mathrm{I}_{\mathrm{SC}}\end{array}$} & \multirow{2}{*}{$\begin{array}{l}\text { Assembled } \\
\text { cells }\end{array}$} & \multirow{2}{*}{$\begin{array}{l}9 \text { cells, } \\
3 \text { sizes }\end{array}$} \\
\hline & $\begin{array}{c}\text { From } 65^{\circ} \mathrm{C} \\
\text { to } 185^{\circ} \mathrm{C}\end{array}$ & & & \\
\hline
\end{tabular}

(AM1.5g, $1000 \mathrm{~W} / \mathrm{m}^{2}, 25^{\circ} \mathrm{C}$ ). An Oriel 1A simulator was used for the PSSAT and an Oriel LCS100 simulator was used for the ASSAT. Electrical parameters of cells under test, extracted from under-illumination $I-V$ measurements, were monitored as degradation modes. In this work, we focus on the changes in performance by observing the power at the maximum power point $\left(P_{M P P}\right)$ and the open-circuit voltage $\left(V_{O C}\right)$.

In the PSSAT, six rectangular bare cells of $1 \mathrm{~mm}^{2}, 0.25 \mathrm{~mm}^{2}$ and $0.076 \mathrm{~mm}^{2}$ (two per size) were considered. In this case, cells are not singulated and the base contact is located onto the back surface of the Germanium substrate. Cells are bonded on a copper-covered FR4 board with Indium as shown on Fig.5.a). $I-V$ measurements under one sun are done by contacting cells with probes. In the ASSAT case, rectangular cells (with base contact on the back surface) were fabricated with the same processes as presented previously. However, nine cells $\left(1 \mathrm{~mm}^{2}\right.$, $0.25 \mathrm{~mm}^{2}$ and $0.076 \mathrm{~mm}^{2}$, three per area) were saw-diced and mounted on $\mathrm{Al}$ carriers. Al-wirebonding was used for the front contact and SAC 305 as die-attach. A thermistor was also assembled on each carrier to control temperature of the package. A photograph of a $0.076-\mathrm{mm}^{2}$ cell package is given in Fig.5.b).

\section{Electrical Performance Monitoring}

In Fig. 6 performance changes in solar cells of after the PSSAT (step stress thermal storage) are depicted. We observe that all cells were degraded by the ageing test as a global decline in $P_{M P P} / P_{M P P O}$ occurs. The $P_{M P P} / P_{M P P O}$ is finally extracted between $0.825\left(0.076-\mathrm{mm}^{2}\right.$ cell A) and $0.957\left(1-\mathrm{mm}^{2}\right.$ cell B) and no catastrophic failure were observed. This validates the relative robustness of the developed fabrication processes for all cell dimensions. In addition, a clear dependence between cell size and $P_{M P P}$ changes can be observed. Indeed, a trend

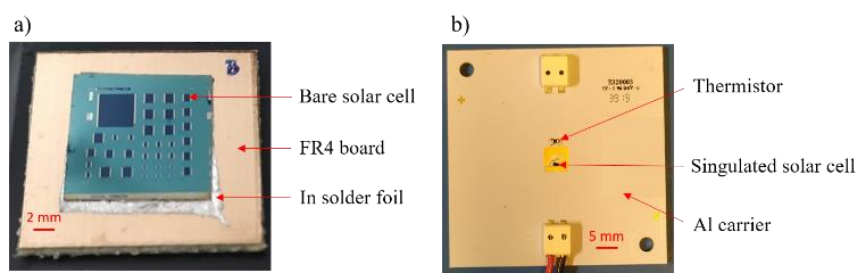

Fig. 5. Photographs of a) a sample with 35 bare cells assembled on a FR4 board for the PSSAT and b) a $0.076-\mathrm{mm}^{2}$ singulated cell on a Al carrier fot the ASSAT.

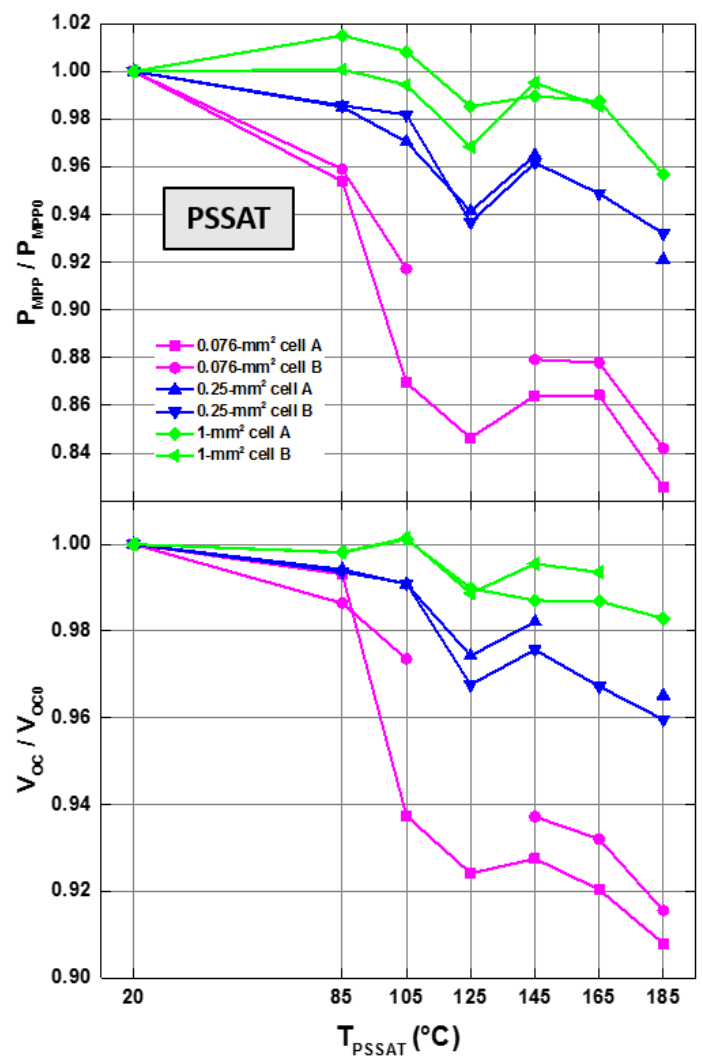

Fig. 6. Performance changes of cells with various size along temperature of the passive step stress ageing test (PSSAT). Top: Variations of the maximal power $P_{M P P}$, relative to the initial value $P_{M P P O}$ and bottom: variations of the open-circuit voltage $V_{O C}$, relative to the initial value $V_{O C O}$.

appears for which the smaller cells are more affected by the $P_{M P P} / P_{M P P O}$ decrease. The difference in $P_{M P P} / P_{M P P O}$ due to cell size can be identified as soon as the first ageing step at $85^{\circ} \mathrm{C}$. The gap due to cell size is extending until the $125-^{\circ} \mathrm{C}$ step. This indicates that degradation processes that affect cells by their size occur at relatively low temperature After $125^{\circ} \mathrm{C}$, changes in $P_{M P P} / P_{M P P O}$ are very similar, within $5.5 \%$, regardless the cell size. These processes also affect the $\mathrm{V}_{\mathrm{OC}}$ as can be seen in the bottom part of the same figure. Based on (1) and (2), $V_{O C}$ monitoring can give information on the recombination processes. We can observe on the $V_{O C} / V_{O C O}$ plot that changes follow the same trend as the one observed for $P_{M P P} / P_{M P P O}$. Indeed, at the end of the PSSAT, $V_{O C} / V_{O C O}$ clearly depends on cell dimensions with a low value of 0.908 for the $0.076-\mathrm{mm}^{2}$ cell and a high value of 0.983 for the $1-\mathrm{mm}^{2}$ cell. These results indicate an increasing impact of recombination with the miniaturization of the cells after PSSAT. However, results are very encouraging for this non-mature technology as no catastrophic failure was observed, even with the high stress level induced by the ageing test.

Fig. 7 illustrates the effects of ASSAT (step stress thermal storage + current injection $\equiv 1000 \times I_{S C}$ ) on the electrical performances of cells, depending on their size. In the top part of Fig. 7, we observe a global decrease of the $P_{M P P} / P_{M P P O}$, proving that all cells were degraded by the ASSAT. The final values for $P_{M P P} / P_{M P P O}$ are comprised between 0.931 


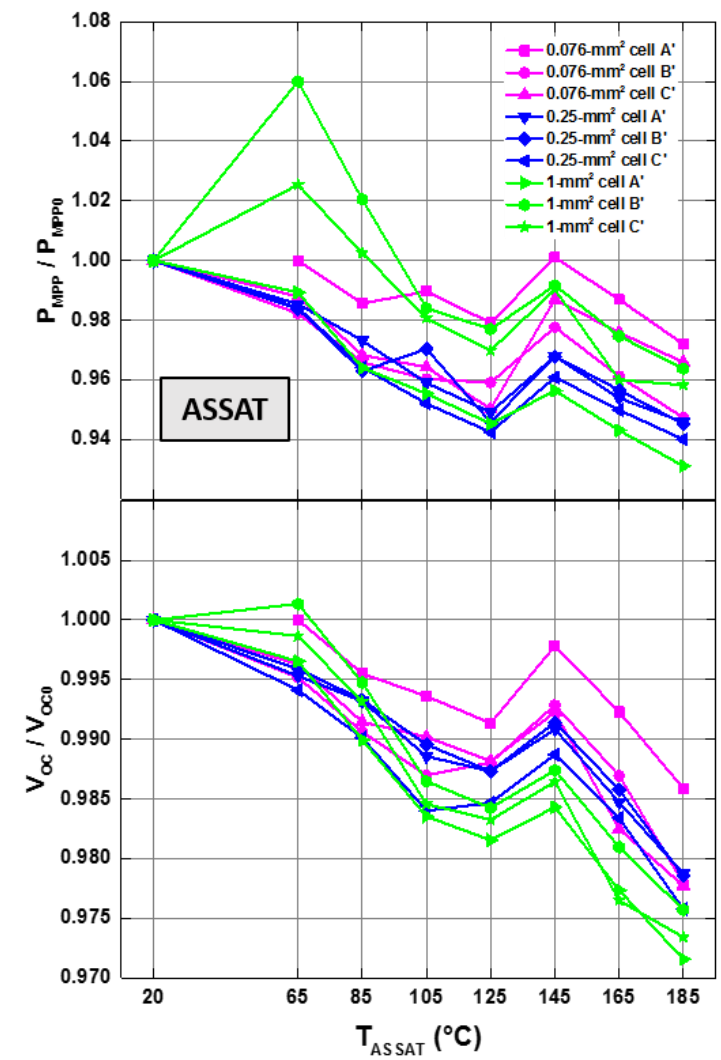

Fig. 7. Performance changes of cells with various size along temperature of the passive step stress ageing test (ASSAT). Top: Variations of the maximal power, relative to the initial value and bottom: variations of the open-circuit voltage, relative to the initial value.

$\left(1-\mathrm{mm}^{2}\right.$ cell $)$ and $0.972\left(0.076-\mathrm{mm}^{2}\right.$ cell), which is higher than the ones observed in the PSSAT, confirming the robustness of the fabricated cells. We can notice that besides fluctuations, no clear trend of variations with cell size can be observed on the $P_{M P P} / P_{M P P O}$ plot. However, whereas the $V_{O C}$ of all cells is affected, it can be seen that the one of $1-\mathrm{mm}^{2}$ cells is slightly more affected (i.e. decrease of $1.4 \%$ ) by ageing and $V_{O C} / V_{O C O}$ ratio is equal to 0.972 for $1-\mathrm{mm}^{2}$ cell $\mathrm{A}^{\prime}$ and 0.986 for $1-\mathrm{mm}^{2}$ cell A' by the end of the ASSAT. Considering that quite high stressing conditions have been considered $\left(T_{A S S A T}=185^{\circ} \mathrm{C}\right.$ and a constant current injection of $1000 \times I_{S C}$ ), very small variations of the electrical parameters have been observed. Whereas the effect of cell size on $P_{M P P}$ is not so clear than for PSSAT, microcells and larger cells have shown very good robustness under ASSAT.

The difference between PSSAT and ASSAT can be explained by more aggressive stress conditions for thermal storage only, as previously reported by Eltermann et al, or by the thermal step at $230{ }^{\circ} \mathrm{C}$ required for cells mounting process used for ASSAT that may have slightly modified the cells [7].

\section{CONCLUSION \& DisCUSSION}

In this work, cells were fabricated with microfabrication processes to allow various geometries and dimensions down to $0.068 \mathrm{~mm}^{2}$, with standard or front base contacts. The use of microelectronics-inspired processes allowed high wafer throughput. Performance of the smaller cells are affected by perimeter recombination, which dominate the recombination mechanisms that take place in the cells. A $V_{O C}$ drop of $8.1 \%$ under one sun was measured when reducing cell area from $1 \mathrm{~mm}^{2}$ to $0.076 \mathrm{~mm}^{2}$ but becomes negligible under high concentration illumination.

A study of the robustness of the fabricated cells was also performed. Both passive and active step stress accelerated tests (PSSAT and ASSAT) were considered and designed to investigate the impact of the cell size on their long-term performance. Whereas no catastrophic failure was observed, higher performance changes occurred in the PSSAT with a minimum $P_{M M P} / P_{M M P O}$ of 0.825 at the end of the test (up to $185^{\circ} \mathrm{C}$ ). Similarly, Eltermann et al. have shown that thermal storage only, compared to thermal storage coupled with current injection and current injection only, led to the most severe degradation of the CPV cells [7]. However, using current injection in ageing tests is often considered as a correct stressing method by the CPV community to simulate photogeneration. These combined stresses aim at better highlighting degradation mechanisms susceptible to appear in real-conditions operation, with a current flowing through the junctions and contacts. Using this technique, we have shown a very promising minimum $P_{M M P} / P_{M M P O}$ of 0.931 at the end of the ASSAT. These results are very encouraging although active ageing may create degradations different from the ones related to nominalconditions operation. Indeed, it was shown that current injection generates a very different current density distribution in the cell structure [6]. This may overstress some part while being too gentle on other and lead to degradation dissimilarities. However, no failure analysis was intended in this robustness investigation work. It was finally demonstrated a globally higher robustness of the smallest cells $\left(0.076 \mathrm{~mm}^{2}\right)$ with a maximum $P_{M M P} / P_{M M P O}$ of 0.972 at the end of the ASSAT $\left(185^{\circ} \mathrm{C}\right)$. From the results obtained in our study, a similar a lifespan in operating conditions for microcells compared to larger cells is expected. Further works will include a comprehensive analysis of the measured degradations.

\section{ACKNOWLEDGMENT}

LN2 is an International Research Laboratory (UMI 3463) between Université de Sherbrooke, CNRS Université de Lyon (INSA, Centrale, CPE) and Université Grenoble Alpes. It is supported by the Fonds de Recherche du Québec Nature et Technologie (FRQNT). The support of Quebec MEI-PROMPT, NSERC and STACE is also acknowledged.

\section{REFERENCES}

[1] C. Domínguez, N. Jost, S. Askins, M. Victoria, I, Antón, “A review of the promises and challenges of micro-concentrator photovoltaics," presented at the 13th International Conference on Concentrator Photovoltaic Systems (CPV-13), Ottawa, Canada, May 2017, p. 080003, doi: 10.1063/1.5001441.

[2] P. Albert et al., "Front-contacted Multijunction Micro Cells: Fabrication and Characterization," presented at the 14th International Conference on Concentrator Photovoltaic Systems (CPV-14), Puertollano, Spain, Apr. 2017.

[3] J. R. González et al., "Reliability analysis of temperature step-stress tests on III-V high concentrator solar cells," Microelectronics Reliability, vol. 49, no. 7, pp. 673-680, Jul. 2009, doi: 10.1016/j.microrel.2009.04.001.

[4] P. Espinet-González et al., "Evaluation of the reliability of commercial concentrator triple-junction solar cells by means of accelerated life tests (ALT)," presented at the 9th International Conference on Concentrator 
Photovoltaic Systems (CPV-9), Miyazaki, Japan, 2013, pp. 222-225, doi: $10.1063 / 1.4822236$.

[5] N. Núñez et al., "Evaluation of the reliability of high concentrator GaAs solar cells by means of temperature accelerated aging tests: Reliability of GaAs concentrator solar cells," Progress in Photovoltaics: Research and Applications, vol. 21, no. 5 p.1104-1113, May 2012, doi: 10.1002/pip.2212.

[6] P. Espinet-González et al., "Temperature accelerated life test on commercial concentrator III-V triple-junction solar cells and reliability analysis as a function of the operating temperature: Temperature accelerated life test," Progress in Photovoltaics: Research and Applications, vol. 23, no. 5, pp. 559-569, May 2015, doi: 10.1002/pip.2461.

[7] F. Eltermann, L. Ziegler, M. Wiesenfarth, J. Wilde, and A. W. Bett, "Performance and failure analysis of concentrator solar cells after intensive stressing with thermal, electrical, and combined load," presented at the 13th International Conference on Concentrator Photovoltaic Systems (CPV-13), Ottawa, Canada, 2017, p. 050002, doi: $10.1063 / 1.5001432$.

[8] M. de Lafontaine et al., "Influence of plasma process on III-V/Ge multijunction solar cell via etching," Solar Energy Materials and Solar Cells, vol. 195, pp. 49-54, Jun. 2019, doi: 10.1016/j.solmat.2019.01.048.

[8] R. Homier et al., "Antireflection Coating Design for Triple-Junction IIIV/Ge High-Efficiency Solar Cells Using Low Absorption PECVD Silicon Nitride," IEEE Journal of Photovoltaics, vol. 2, no. 3, pp. 393397, Jul. 2012, doi: 10.1109/JPHOTOV.2012.2198793.

[9] M. Darnon et al., "Deep germanium etching using time multiplexed plasma etching," Journal of Vacuum Science \& Technology B, Nanotechnology and Microelectronics: Materials, Processing, Measurement, and Phenomena, no. 33, p. 060605, Nov. 2015.

[11] P. Albert et al., "High-voltage Low-current Multijunction Monolithic Interconnected Microcells," presented at the 15th International Conference on Concentrator Photovoltaics Systems (CPV-15), Fez, Morocco, Mar. 2019.

[11] M. A. Green, "Solar cell fill factors - General graph and empirical expressions," Solid State Electronics, vol. 24, p. 788, Aug. 1981, doi: 10.1016/0038-1101(81)90062-9. 